\title{
Cancer in Israel: Incidence and Trends
}

\author{
Zaher Bahouth* and Ofer Nativ \\ Department of Urology, School of Medicine, Israel
}

Submission: February 03, 2017; Published: April 06, 2017

*Corresponding author: Zaher Bahouth, Department of Urology, Bnai-Zion Medical Center, School of Medicine, Technion, Haifa, Israel, Tel: 0097248359542; Email: Zaher.bahouth@b-zion.org.il

\section{Abstract}

Background: The incidence of testicular cancer is steadily increasing in most parts of the world, with European countries leading the list. In Asia, Israel has the highest age-standardized ratio. However, Israel has several sub-populations with various ethnics and potentially significant differences in incidence.

Objectives: To report the incidence and trends of testicular cancer in Israel in the past two decades and to show the differences between the different ethnic groups.

Methods: After a legal instruction in 1982, all medical centers in Israel started to report every patient with any cancerous disease to the Israel National Cancer Registry (INCR). Data from the INCR is freely available online. We retrieved data on testicular cancer in Israel and analyzed it. No statistical comparison was done.

Results: In Israel, there is a trend of increasing incidence of testicular cancer. Ashkenazi Jewish have the highest risk of developing testicular cancer, with an incidence approaching some European countries. All sub-populations in Israel showed a steady increase in incidence of testicular cancer.

Conclusions: Ashkenazi Jews has a 5.7-fold the risk of Sephardi Jews or Israeli Arabs, and 8-fold the risk of Asian Jews. The incidence of testicular cancer in Israel is increasing in all sub-populations.

Keywords: Testicular cancer; GLOBOCAN; INCR; Israel

\section{Introduction}

The incidence of testicular cancer has increased steadily over the past 20 years in the United States and Europe [1-3]. Data from other parts of the world shows a similar trend of increasing incidence [4]. Based on data from GLOBOCAN 2012, Norway has the highest age-standardized incidence rate (ASR) of 12.2 per 100,000 citizens. Other European countries have a high ASR, most of which above 7.0 [5].

Israel has the highest ASR among all Asian countries [5]. There are three large and distinct sub-populations in Israel: Ashkenazi Jews-descendants of Jews from central and eastern Europe; Sephardi Jews who are descendants of Jews from Iberia and Israeli Arabs. Moreover, Israel includes other smaller subpopulations such as Asian Jews and foreign workers.

This report presents an updated rates and trends of testicular cancer in Israel based on data from the Israel National Cancer Registry (INCR).

\section{Materials and Methods}

Data on the incidence of testicular cancer patients in Israel was obtained from the INCR. INCR was established in 1960 and reporting of newly diagnosed cancer cases has been mandatory by Israeli law since 1982 . The INCR covers the entire Israeli population (more than eight millions citizens) and receives data from several sources including hospitals, pathology and cytology laboratories, death certificates from local health authorities and cause of death information from Israel Central Bureau of Statistics [6]. Data is available online and updated regularly (last update on May 5, 2016). The last year of fully updated data regarding testicular cancer was 2013. All data presented in our study was extracted from the Ministry of Health online database and edited as needed.

We obtained data on the incidence of testicular cancer in the different ethnic groups in Israel and compared the ASR between them. We also analyzed the trends in the incidence of testicular cancer since 1982. ASR is reported as new cases per 100,000 persons per year and standardized by Segi world standard population.

The INCR has trained registrars whom, for each case, use the available documents to establish site and morphology according to ICD-0-3 coding and record grade, size of tumor, treatment 
provided and stage according to the SEER Summary Staging Manual. It should be emphasized that these data do not include

benign testicular neoplasms, neoplasms of uncertain behavior or testicular lymphomas.

Results

Table 1: ASR and actuarial number of patients diagnosed with testicular cancer in Israel between 1982-2013, in all ethnic groups.

\begin{tabular}{|c|c|c|c|c|c|c|c|}
\hline \multirow{2}{*}{ Year } & \multicolumn{5}{|c|}{ Jewish } & \multirow{2}{*}{ Arabs } & \multirow{2}{*}{ Others } \\
\hline & Overall & Asia & Sephardi & Ashkenazi & Israeli & & \\
\hline 1982 & $38(2.33)$ & $3(1.02)$ & $4(1.44)$ & $12(4.27)$ & $19(2.01)$ & $4(2.35)$ & 0 \\
\hline 1983 & $36(2.06)$ & 0 & $4(1.29)$ & $9(2.4)$ & $23(2.7)$ & $4(1.11)$ & 0 \\
\hline 1984 & 37 (2.08) & $5(6.84)$ & 0 & $10(1.93)$ & $22(2.02)$ & $1(0.43)$ & 0 \\
\hline 1985 & $56(2.99)$ & $2(1.11)$ & $1(0.43)$ & $24(8.64)$ & $29(3.41)$ & $1(0.21)$ & 0 \\
\hline 1986 & $40(2.28)$ & $3(0.94)$ & $3(0.87)$ & $13(3.31)$ & $21(2.52)$ & $3(0.76)$ & 0 \\
\hline 1987 & 46 (2.59) & 0 & $1(0.39)$ & $21(7.26)$ & $24(2.53)$ & $1(0.25)$ & 1 \\
\hline 1988 & 58 (3.17) & $1(0.25)$ & $3(2.52)$ & 22 (6.89) & 32 (2.49) & $2(0.43)$ & 1 \\
\hline 1989 & $60(3.15)$ & $2(1.81)$ & $1(0.27)$ & 18 (5.5) & $39(4.76)$ & $3(0.61)$ & 2 \\
\hline 1990 & $53(2.75)$ & 5 (1.59) & $1(0.98)$ & $16(3.5)$ & $31(3.14)$ & $4(0.98)$ & 0 \\
\hline 1991 & $70(3.30)$ & $6(3.15)$ & $3(4.79)$ & $24(5.07)$ & $37(2.82)$ & 3 (1.01) & 1 \\
\hline 1992 & $60(2.83)$ & $3(0.92)$ & 0 & $15(2.61)$ & $42(4.15)$ & $2(0.32)$ & 3 \\
\hline 1993 & $70(3.16)$ & $1(0.29)$ & $1(0.52)$ & 21 (3.79) & $47(3.24)$ & $8(1.36)$ & 4 \\
\hline 1994 & $71(3.16)$ & $2(0.56)$ & $2(0.57)$ & $24(4.08)$ & 43 (3.3) & $4(0.95)$ & 1 \\
\hline 1995 & 75 (3.35) & $2(1.08)$ & $2(0.55)$ & $20(3.17)$ & 51 (3.67) & 8 (1.69) & 1 \\
\hline 1996 & $72(3.11)$ & $4(0.96)$ & $4(1.11)$ & $25(4.66)$ & 39 (2.35) & 10 (1.95) & 4 \\
\hline 1997 & 93 (3.97) & $2(0.94)$ & $1(0.55)$ & $22(3.68)$ & $68(4.43)$ & 8 (1.77) & 0 \\
\hline 1998 & $88(3.61)$ & $3(2.88)$ & $2(0.54)$ & $21(2.72)$ & $61(4.06)$ & 9 (1.37) & 5 \\
\hline 1999 & $101(4.00)$ & $4(4.23)$ & $2(2.47)$ & $27(4.34)$ & 68 (3.95) & $7(1.10)$ & 5 \\
\hline 2000 & 97 (3.93) & $2(2.39)$ & $4(1.2)$ & 14 (1.9) & 77 (4.65) & $11(1.70)$ & 3 \\
\hline 2001 & $112(4.37)$ & $1(0.28)$ & $2(1.1)$ & $29(3.64)$ & $80(4.55)$ & $10(1.64)$ & 5 \\
\hline 2002 & $122(4.76)$ & $2(0.47)$ & $4(2.71)$ & $29(4.03)$ & 87 (4.69) & 11 (1.89) & 4 \\
\hline 2003 & $118(4.48)$ & $4(3.76)$ & $1(0.27)$ & 29 (3.99) & $84(4.25)$ & 12 (1.87) & 4 \\
\hline 2004 & $115(4.40)$ & $1(0.19)$ & $3(2.38)$ & $28(3.56)$ & $83(4.52)$ & 12 (1.92) & 6 \\
\hline 2005 & $126(4.70)$ & $1(0.25)$ & 0 & $24(3.17)$ & $101(5.18)$ & 10 (1.47) & 2 \\
\hline 2006 & $121(4.41)$ & 0 & $3(3.20)$ & $20(3.67)$ & $97(4.73)$ & $16(2.30)$ & 5 \\
\hline 2007 & $142(5.11)$ & 0 & $1(1.46)$ & $30(5.44)$ & $111(5.26)$ & 10 (1.33) & 7 \\
\hline 2008 & $115(4.08)$ & $2(0.33)$ & $1(0.53)$ & $20(3.51)$ & $91(4.28)$ & $10(1.43)$ & 4 \\
\hline 2009 & $135(4.57)$ & $2(0.19)$ & 0 & $18(3.33)$ & 115 (5.57) & $16(2.09)$ & 10 \\
\hline 2010 & $134(4.68)$ & $1(0.09)$ & 0 & $25(5.29)$ & $108(5.0)$ & 10 (1.39) & 7 \\
\hline 2011 & $131(4.42)$ & 0 & $2(1.86)$ & $41(7.68)$ & $87(3.72)$ & 23 (2.98) & 3 \\
\hline 2012 & $150(4.99)$ & $2(3.13)$ & $1(1.33)$ & $32(6.07)$ & $114(4.89)$ & 10 (1.19) & 9 \\
\hline 2013 & $135(4.53)$ & NA & NA & NA & NA & $28(3.13)$ & 6 \\
\hline Mean & $88(3.63)$ & $2.5(1.52)$ & $2.2(1.35)$ & $22(4.29)$ & $62.3(3.8)$ & 7.8 (1.35) & 4 \\
\hline Median & $88(3.61)$ & $2(0.95)$ & $2(1.1)$ & 22 (3.79) & $61(4)$ & 8 (1.37) & 4 \\
\hline
\end{tabular}

NA: Not Available. All numbers are actual number of cases. Numbers in brackets are ASR (1:100.000). No ASR for other groups.

We retrieved data from 1982 through 2013. In 2013, with testicular cancer in Israel between 1982-2013, divided into testicular cancer was diagnosed in 163 patients in Israel: 135 Jewish and 28 Arabs. This translates into ASR of 4.51 for the Jewish population and 3.13 for the Arabs population. Table 1 shows the ASR and the actuarial number of patients diagnosed

Figure 1 shows the ASR of patients diagnosed with testicular cancer in Jewish and Arab males in Israel, from 1982 to 2013 
with a trend line for each sub-population. This figure shows a trend of increasing incidence through the past two decades.

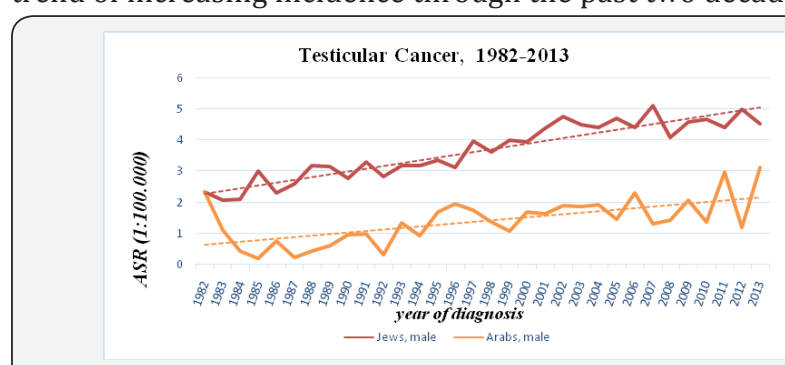

Figure 1: ASR of patients diagnosed with testicular cancer in Jewish and Arab males in Israel, from 1982 to 2013 with a trend line for each sub-population.

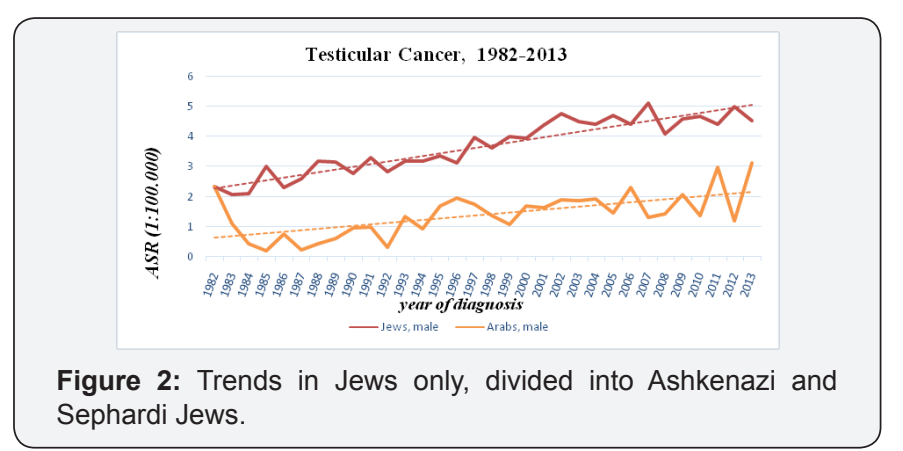

Figure 2 shows the trends in Jewish males only, divided into two groups: Ashkenazi and Sephardi Jews. In this figure, we can see an ASR of 4.0-8.0 in Ashkenazi Jews compared to less than 2 in Sephardi Jews. Figure 3 shows the ASR of all the subpopulations in Israel, with the highest rate being in Ashkenazi Jews.

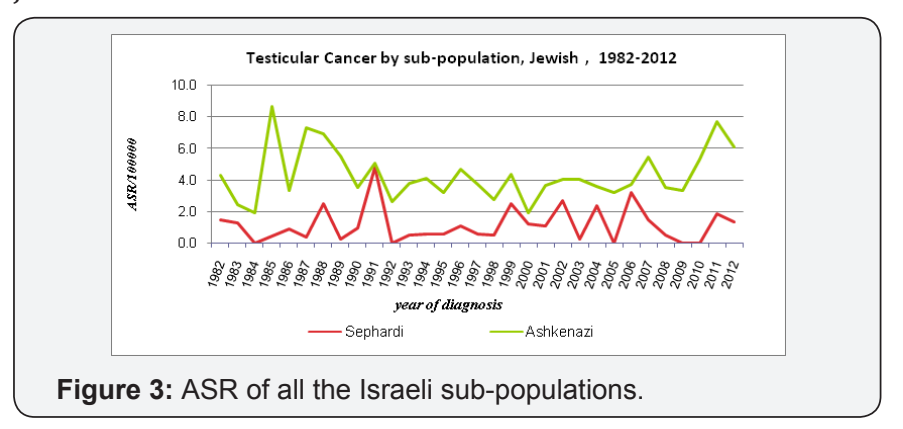

\section{Discussion}

Testicular cancer is the most common malignancy among men in their 20-40 years of age [7]. The incidence of testicular cancer appears to be increasing worldwide [8]. In our study, Israel is no different; there is an obvious trend of increasing incidence among all sub-populations in Israel. The trend of increasing incidence is obvious in Jewish and Arab men.

The incidence of testicular cancer varies significantly according to geographic region with rates being highest in Scandinavia and lowest in Asia [9]. However, Israel has the highest rates of testicular cancer among all Asian countries [5]. Genetic and environmental factors could possibly be contributing factors to the increasing incidence of testicular cancer $[10,11]$.
These factors could also explain the highest rates of testicular cancer in Israel compared to other Asian countries and the high rates in Ashkenazi Jewish-descendants of European countries.

Significant differences in ASR exist in same countries in different ethnic groups [12]. For example, Horner et al showed that the incidence of testicular cancer in white non-Hispanic Americans is five times higher than Black Americans [7]. In Israel, we showed that the risk in Ashkenazi Jews is, on average, 5.7 times higher than in Sephardi Jews and Israeli Arabs, and 8 times higher than Jewish from Asian countries.

This is mainly an epidemiological study, and as such, has some inherent limitations. No statistical studies can be done to compare the statistical significance of the differences between the ASR. Data in the registry is limited, and some crucial data was not available for us in this study. Moreover, a child of an Ashkenazi parents, who was born in Israel is registered as an Israeli, and another child of two Sephardi parents who was born in Israel is registered as Israeli.

\section{Conclusion}

The incidence of testicular cancer is still increasing in Israel, as in several other countries around the world. Ashkenazi Jewish males are at the highest risk of developing testicular cancer in Israel, with ASR approaching the highest populations in Scandinavia.

\section{References}

1. Nigam M, Aschebrook-Kilfoy B, Shikanov S, Eggener S (2014) Increasing incidence of testicular cancer in the United States and Europe between 1992 and 2009. World J Urol 33(5): 623-631.

2. Gilbert D, Rapley E, Shipley J (2011) Testicular germ cell tumours: predisposition genes and the male germ cell niche. Nat Rev Cancer 11(4): 278-288.

3. Dalgaard MD, Weinhold N, Edsgärd D, Silver JD, Pers TH, et al. (2012) A genome-wide association study of men with symptoms of testicular dysgenesis syndrome and its network biology interpretation. J Med Genet 49(1): 58-65.

4. Huyghe E, Matsuda T, Thonneau P (2003) Increasing Incidence of Testicular Cancer Worldwide: A Review. J Urol 170(1): 5-11.

5. Ferlay J, Soerjomataram I, Ervik M, Dikshit R, Eser S, et al. (2013) GLOBOCAN 2012 v1.0, Cancer Incidence and Mortality Worldwide in 2012 v1.0. IARC CancerBase No. 11. International Agency for Research on Cancer, France.

6. Anon. Israel National Cancer Registry. Ministry of Health, State of Israel.

7. Horner M, Ries L, Krapcho M (2009) SEER cancer statistics review, 1975- 2006. Bethesda (MD): National Cancer Institute, 2009.

8. Purdue MP, Devesa SS, Sigurdson AJ, McGlynn KA (2005) International patterns and trends in testis cancer incidence. Int J Cancer 115(5): 822-827.

9. Weijl NI, Rutten MFJ, Zwinderman AH, Keizer HJ, Nooy MA, et al. (2000) Thromboembolic Events During Chemotherapy for Germ Cell Cancer: A Cohort Study and Review of the Literature. J Clin Oncol 18(10): 21692178. 
10. Mai PL, Chen BE, Tucker K, Friedlander M, Phillips KA, et al. (2009) Younger age-at-diagnosis for familial malignant testicular germ cell tumor. Fam Cancer 8(4): 451-456.

11. Sonne SB, Kristensen DM, Novotny GW, Olesen IA, Nielsen JE, et al.
(2008) Testicular dysgenesis syndrome and the origin of carcinoma in situ testis. Int J Androl 31(2): 275-287.

12. Wein AJ, Kavoussi LR, Partin AW, Peters CA, (2016). Campbell-Walsh urology $\left(11^{\text {th }}\right.$ edn). Elsevier, Philadelphia, PA, USA.

\section{Your next submission with Juniper Publishers will reach you the below assets}

- Quality Editorial service

- Swift Peer Review

- Reprints availability

- E-prints Service

- Manuscript Podcast for convenient understanding

- Global attainment for your research

- Manuscript accessibility in different formats

( Pdf, E-pub, Full Text, Audio)

- Unceasing customer service

Track the below URL for one-step submission https://juniperpublishers.com/online-submission.php 